Egyptian Journal of Aquatic Biology \& Fisheries

Zoology Department, Faculty of Science,

Ain Shams University, Cairo, Egypt.

ISSN $1110-6131$

Vol. 24(1): 541- 552 (2020)

www.ejabf.journals.ekb.eg

\title{
Seasonality of Fish Catch and Fish Prices in Natural Egyptian Fisheries
}

\author{
Shimaa I. Maiyza ${ }^{1, *}$ and Ibrahim A.El-karyoney ${ }^{2}$ \\ 1. National Institute of Oceanography and Fisheries (NIOF), Red Sea branch, Egypt. \\ 2. National Institute of Oceanography and Fisheries (NIOF), Alexandria branch, Egypt. \\ *Corresponding Author: shemo_iam@yahoo.com
}

ARTICLE INFO

\section{Article History:}

Received: July 8, 2019

Accepted: Dec. 27, 2019

Online: Jan. 2020

Keywords:

Seasonal Index,

Egyptian Fisheries

Med. Sea,

Red Sea,

fish catch,

fish prices.

\section{ABSTRACT}

Seasonal index is an important indicator to study seasonal variations in any studied phenomena which can be changed regularly in an interval less than one year. This paper aimed to study the relationship between fish catch $\&$ fish prices "Seasonal Index" of Egyptian Natural Fisheries. This relationship determines type of fisheries production, if this relationship is positive, then the fish catch from this fisheries are totally economic. Whereas the negative relationship means the fisheries need to apply new developing programs to be in economic production.

The present work concluded that:

(1) It is important to increase, or at least maintain fish catch in total Egyptian natural fisheries, total fresh water fisheries, total marine fisheries, and individual Red Sea fisheries due to the positive relationship between fish catch seasonal index $(\%)$ and fish prices seasonal index.

(2) More and actual effective developing programs must be applied in total lakes fisheries and individual Mediterranean Sea fisheries to overcome the present negative relationship between seasonal index of fish catch and fish prices.

\section{INTRODUCTION}

Seasonal index it is an important indicator to study seasonal variations in any studied phenomena which change regularly in an interval less than one year. Seasonal variations are one of components of time series beside secular trend, cyclical or periodical variations, and accidental variations, so to study seasonal variations we must exclude the other variations.

So it is important to find out the relation between fish catch and fish prices "Seasonal Index" to all resources of natural fisheries in Egypt, because these fisheries are affected many variable factors, which reflect the difficult of control the fish catch from Natural Fisheries, to know if the fish catch from this fisheries are totally economic, or need to apply more development programs to be in economic production. 
The aim of this paper is study seasonal variation of natural Egyptian fisheries, through two main ways; (1) seasonal index of fish catch, (2) seasonal index of fish prices, to all resources of natural fisheries in Egypt. Because natural fisheries in Egypt have the largest fishing area and the least amount of fish catch compared to the fish production from aquaculture in recent years. To find out the relationship between fish catch $\&$ fish prices "Seasonal Index"

\section{MATERIALS AND METHODS}

The present study is depending on collecting fisheries official data from General Authority for Fish Resources Development (GAFRD) during the period (2009-2014), and calculated the seasonal index of fish catch and fish prices of the total natural Egyptian fisheries and its sources.

Seasonal index it is an important indicator to study seasonal variations in any studied phenomena which change regularly in an interval less than one year. Seasonal variations are one of components of time series beside secular trend, cyclical or periodical variations, and accidental variations, so to study seasonal variations we must exclude the other variations.

To calculate seasonal index of used data, it has been used a base value of 100 percent (AgriLIFE EXTENSION), which calculated by specific steps as follow, first calculate the monthly average values of fish catch (tons) and fish prices (LE/ $\mathrm{kg}$ ) during the period of study (2009-2014) to eliminate the random influence, hence this figures represent only monthly seasonality variations,(Carbunaru\&Bacescu,2013), Second calculated the estimated value to every month by using linear time trend equation (Ordinary Least Squares) for the monthly average values data, and finally division the true value on estimated value to every month (\%).

Also calculate the correlation coefficient to find out the relation between fish catch \& fish prices "Seasonal Index", if this relationship positive then production must be continue from the fisheries because this will increase income from these fisheries, so the fish production from this fishery is totally economic, but if this relationship is negative we should develop these fisheries to be economic production.

\section{RESULTS AND CONCLUSIONS}

\section{Evaluation and relative importance of fish catch and area in natural Egyptian fisheries.}

Natural Egyptian fisheries consist of many sources (marine fisheries, lake fisheries, and fresh water fisheries). These fisheries area are about $13.2 * 10^{6}$ acre during the period (2009-2014), which represent about 95.0\% of Egyptian fisheries area. The aquaculture fish production in Egypt represents 27.3\% of Egyptian fisheries production (Table. 1), due to the development program focus on fish aquaculture in fresh water since the 
eighteenth of last decade until now, in addition to entry to marine culture in basins recently, (Maiyza, SH.I., 2015).

Table.1. Evaluation and relative importance of fish catch and area in Egyptian fisheries during the period (2009-2014)

\section{Egyptian fisheries}

Items Year

2009

2010

2011

Fish catch

2012

(tons*10 ${ }^{3}$ )

2013

356.9

Natural
fisheries Aquaculture Total

2014

344.8

387.4

385.2

705.5

1092.9

919.6

1304.8

375.4

986.8

1362.2

Average

367.3

\begin{tabular}{cccc}
\hline \% Egyptian fisheries & $\mathbf{2 7 . 3}$ & $\mathbf{7 2 . 7}$ & $\mathbf{1 0 0 . 0}$ \\
\hline $\begin{array}{c}\text { Area } \\
\left(\text { acre*10 }^{6} \text { ) }\right.\end{array}$ & 13.205 & 0.7 & 13.905 \\
\hline \% Egyptian fisheries & $\mathbf{9 5 . 0}$ & $\mathbf{5 . 0}$ & $\mathbf{1 0 0 . 0}$ \\
\hline
\end{tabular}

\begin{tabular}{cccc}
\hline \% Egyptian fisheries & $\mathbf{2 7 . 3}$ & $\mathbf{7 2 . 7}$ & $\mathbf{1 0 0 . 0}$ \\
\hline $\begin{array}{c}\text { Area } \\
\left(\text { acre*10 }^{6} \text { ) }\right.\end{array}$ & 13.205 & 0.7 & 13.905 \\
\hline \% Egyptian fisheries & $\mathbf{9 5 . 0}$ & $\mathbf{5 . 0}$ & $\mathbf{1 0 0 . 0}$ \\
\hline
\end{tabular}

1017.7

1371.9

1097.5

1454.4

1137.1

1481.9

Source:

1- Collected from; Maiyza, SH.I. (2015), An Economic Study of Fish Production In Alexandria Mediterranean Sea Fisheries, Ph.D., Faculty of Agriculture, Alexandria University, Egypt.

2- GAFRD, Yearbook of Fishery statistics, (2009-2014), Cairo, 2016.

So, it is important to study the Natural Fisheries, which are affected many variable factors such as weathering conditions (storms, humidity, wind...etc.), biological relationships among fish and other living organisms in their ecosystem, economic factors (fish prices, fishing effort, capital...etc.), environmental factors which associate with aquatic pollution from all types (sewages, agriculture, domestic, industry, recreation, oil spill from ports and platforms,... etc.), in addition to the harmful fishing activities by using illegal fishing tools. What mention before reflect the difficult of control the fish catch from Natural Fisheries as opposed to what exists in aquaculture.

Moreover, it is obvious from studying the relative importance of fish production from Egyptian natural fisheries (Table. 2), that lake fisheries are the largest relative importance that contribute about $47.26 \%$ of the annual average of total fish production from Egyptian natural fisheries during the period (2009-2014), whereas marine and freshwater fisheries contribute about $31.77 \%$ \& $20.97 \%$ of the annual average of total fish production from Egyptian natural fisheries respectively during the same study period.

Despite the fact that the Marine fisheries area exceed that of lakes and fresh water, which have an area of $11.2 * 10^{6}, 1.818 * 10^{6}$, and $0.187 * 10^{6}$ acre respectively, but lake 
fisheries are bigger than marine fisheries in relative importance of fish production due to the potential of applying development programs easily in lake fisheries. Because lakes fisheries are smaller in its area and have small range of climate change effect compared to marine fisheries, (Maiyza, 2015). But when studying each source separately, it is shows that Mediterranean Sea $\left(6.8^{*} 10^{6}\right.$ acre $)$ is bigger than Red sea $\left(4.4 * 10^{6}\right.$ acre $)$ in its relative importance of fish production from Marine fisheries, which contribute about $19.47 \%$ \& $12.30 \%$ of the annual average of total fish production from Egyptian natural fisheries during the period of study (Maiyza, 2015).

In lakes fisheries, the northern delta ecosystems are superior to its counterpart (34.89\%) in inland lakes $(11.23 \%)$ and coastal lagoons $(1.14 \%)$ in its relative importance of fish production - (Table. 2), although the area of inland lakes $\left(1.399^{*} 10^{6}\right.$ acre) superior to northern delta lakes $\left(0.252 * 10^{6}\right.$ acre $)$ and coastal lagoons $\left(0.167 * 10^{6}\right.$ acre $)$.

Table.2. Evaluation and relative importance of fish catch in natural Egyptian fisheries during the period (2009-2014).

(tons)

\section{Natural Egyptian fisheries}

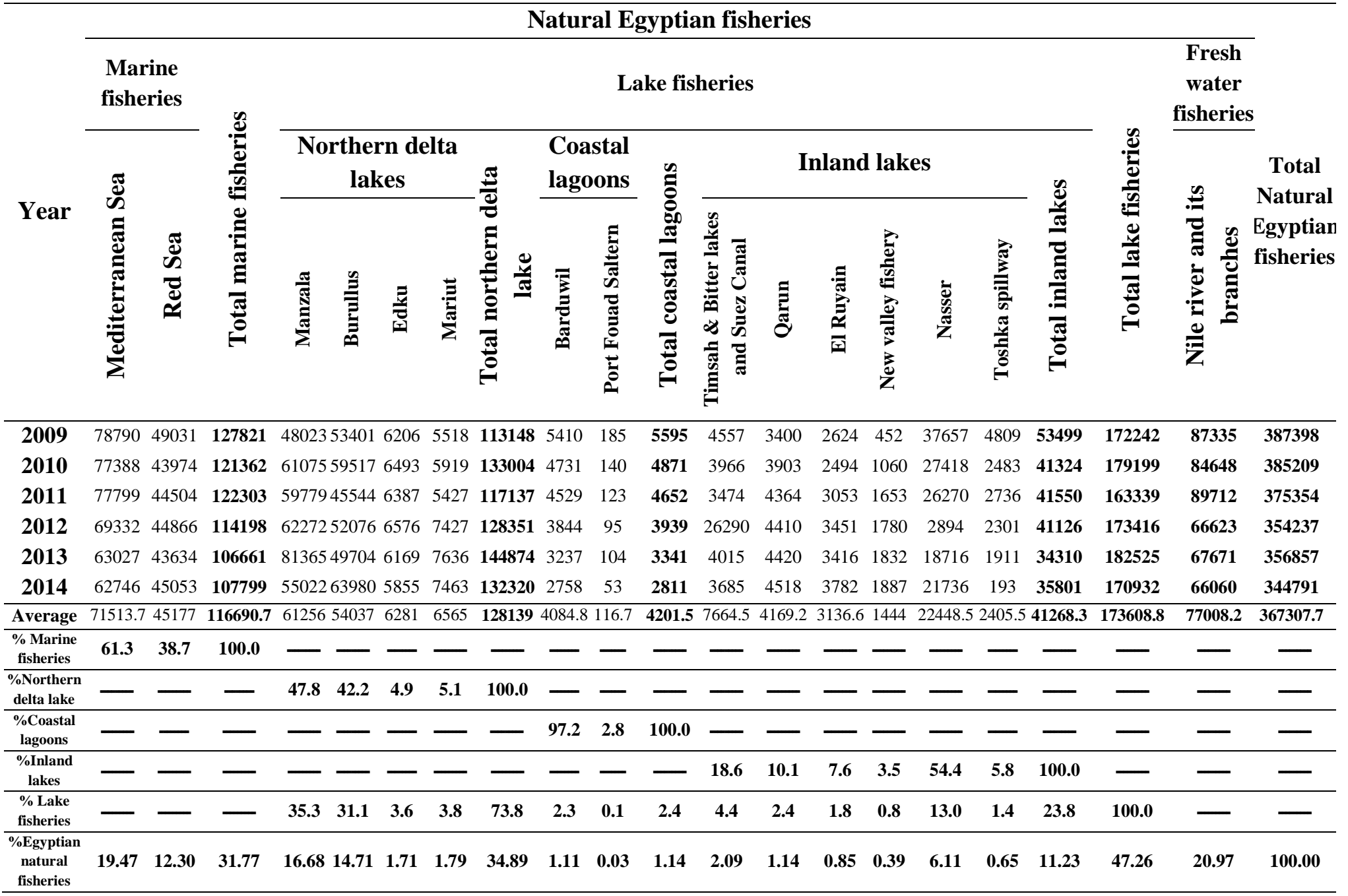

Source: collected from: GAFRD, Yearbook of Fishery statistics, (2009-2014), Cairo, 2016. 
So, although the inland lakes area is bigger than northern delta lakes, but its relative importance of fish production is smaller because of two main reasons: (1) the renewed water of northern delta lakes, due to their communication of Mediterranean Sea by small holes, (Water Quality Assessment, 1996), (2)application law of stop fishing in inland lakes from May to September (5 months) such as, Qarun (May: June), El Ruyain (July) and New valley fishery (August- September), Whereas stop fishing applied in coastal lagoons in (January: June\& December) such as, Barduwil (January: April \& December) and Port Fouad Saltern (January: June), (GAFRD, 2014).

\section{Seasonal Index of fish catch in natural Egyptian fisheries.}

To study the seasonal index of fish catch, we applied the steps mentioned before to the data on table.3. Seasonality Index of fish catch in natural Egyptian fisheries come from variability of seasonality of marine, lakes and freshwater fisheries, which increasing in months (January, March, April, July, September, October, November), and decrease in other months- (Table. 4).

Table.3. Monthly average of fish catch in natural Egyptian fisheries during the period (2009-2014)

(Tons)

\begin{tabular}{|c|c|c|c|c|c|c|c|c|c|}
\hline \multirow[b]{2}{*}{ Months } & \multicolumn{2}{|c|}{ Marine fisheries } & \multirow{2}{*}{$\begin{array}{c}\text { Total } \\
\text { Marine } \\
\text { fisheries }\end{array}$} & \multicolumn{3}{|c|}{ Lakes fisheries } & \multirow{2}{*}{$\begin{array}{c}\text { Total } \\
\text { Lakes } \\
\text { fisheries }\end{array}$} & \multirow{2}{*}{$\begin{array}{c}\text { Fresh } \\
\text { water } \\
\text { fisheries }\end{array}$} & \multirow{2}{*}{$\begin{array}{l}\text { Natural } \\
\text { Egyptian } \\
\text { fisheries }\end{array}$} \\
\hline & $\begin{array}{c}\text { Mediterranean } \\
\text { Sea }\end{array}$ & $\begin{array}{l}\text { Red } \\
\text { Sea }\end{array}$ & & $\begin{array}{c}\text { Northern } \\
\text { delta } \\
\text { lakes }\end{array}$ & $\begin{array}{l}\text { Coastal } \\
\text { lagoons }\end{array}$ & $\begin{array}{l}\text { Inland } \\
\text { lakes }\end{array}$ & & & \\
\hline January & 5041.0 & 4851.3 & 9892.3 & 8923.5 & 21.3 & 3224.7 & 12169.5 & 6614.2 & 28676.0 \\
\hline February & 5264.8 & 3802.2 & 9067.0 & 9311.8 & 0.0 & 3104.5 & 12416.3 & 6251.2 & 27734.5 \\
\hline$\overline{\text { March }}$ & 5551.3 & 4370.7 & 9922.0 & 9588.5 & 0.0 & 4116.8 & 13705.3 & 6298.5 & 29925.8 \\
\hline April & 5899.8 & 3808.2 & 9708.0 & 10168.8 & 501.0 & 3003.7 & 13673.5 & 6531.5 & 29913.0 \\
\hline May & 3927.8 & 3750.5 & 7678.3 & 10456.8 & 948.0 & 1908.0 & 13312.8 & 6539.7 & 27530.8 \\
\hline June & 5743.3 & 1560.0 & 7303.3 & 11077.7 & 517.2 & 3791.3 & 15386.2 & 6493.5 & 29183.0 \\
\hline July & 6903.0 & 1016.5 & 7919.5 & 12376.7 & 384.0 & 3796.6 & 16557.3 & 6577.5 & 31054.3 \\
\hline August & 7323.7 & 299.3 & 7623.0 & 11513.8 & 318.7 & 3628.7 & 15461.2 & 6533.3 & 29617.5 \\
\hline September & 7477.7 & 3884.3 & 11362.0 & 11342.0 & 378.3 & 3561.1 & 15281.4 & 6547.8 & 33191.2 \\
\hline October & 6783.8 & 7133.6 & 13917.4 & 11420.1 & 484.7 & 3791.0 & 15695.8 & 6241.2 & 35854.4 \\
\hline November & 6072.0 & 5299.7 & 11371.7 & 11094.5 & 404.5 & 4509.3 & 16008.3 & 6130.5 & 33510.5 \\
\hline December & 5525.5 & 5400.7 & 10926.2 & 10864.8 & 243.8 & 2832.6 & 13941.2 & 6249.3 & 31116.7 \\
\hline Total & 71513.7 & 45177.0 & 116690.7 & 128139.0 & 4201.5 & 41268.3 & 173608.8 & 77008.2 & 367307.7 \\
\hline Average & 5959.4 & 3764.8 & 9724.2 & 10678.3 & 350.1 & 3439.0 & 14467.4 & 6417.4 & 30609.0 \\
\hline
\end{tabular}

Source: Collected from: GAFRD, Yearbook of Fishery statistics, (2009-2014), Cairo, 2016. 
Table.4. Seasonal index offish catch in natural Egyptian fisheries during the period (2009-2014)

(\%)

\begin{tabular}{|c|c|c|c|c|c|c|c|c|c|}
\hline Statem & Marine fishe & & Total & & es fisherie & & Total & & \\
\hline Months & $\begin{array}{l}\text { Mediterranean } \\
\quad \text { Sea }\end{array}$ & $\begin{array}{l}\text { Red } \\
\text { Sea }\end{array}$ & $\begin{array}{l}\text { fisheries } \\
\text { (M) }\end{array}$ & $\begin{array}{l}\text { Northern } \\
\text { delta } \\
\text { lakes }\end{array}$ & $\begin{array}{l}\text { Coastal } \\
\text { lagoons }\end{array}$ & $\begin{array}{c}\text { Inland } \\
\text { lakes }\end{array}$ & $\begin{array}{l}\text { fisheries } \\
\text { (L) }\end{array}$ & $\begin{array}{l}\text { fisheries } \\
\text { (F) }\end{array}$ & $\begin{array}{l}\text { Egyptian } \\
\text { fisheries }\end{array}$ \\
\hline January & 97.2 & 151 & 118 & 93.81 & 10.0 & 101.7 & 94.32 & 101.4 & 103 \\
\hline February & 99.3 & 114 & 105 & 95.71 & 0.0 & 96.5 & 94.22 & 96.1 & 98 \\
\hline March & $\begin{array}{l}101.3 \\
\end{array}$ & 128 & 112 & 96.52 & 0.0 & 126.0 & 101.73 & 97.2 & 104 \\
\hline April & 105.3 & 108 & 106 & 100.22 & 177.3 & 90.6 & 99.42 & 101.0 & 102 \\
\hline May & 68.2 & 103 & 82 & 100.92 & 309.9 & 56.7 & 94.82 & 101.5 & 92 \\
\hline June & 97.2 & 42 & 76 & 104.82 & 157.0 & 111.0 & 107.43 & 101.0 & 96 \\
\hline July & 114.2 & 27 & 80 & 114.82 & 108.9 & 109.6 & 113.33 & 102.6 & 101 \\
\hline August & 119.3 & 8 & 76 & 104.82 & 84.7 & 103.3 & 103.83 & 102.3 & 94 \\
\hline September & 118.3 & 96 & 110 & 101.22 & 94.8 & 100.0 & 100.73 & 102.8 & 104 \\
\hline October & 105.3 & 173 & 132 & 100.02 & 114.7 & 105.0 & 101.53 & 98.3 & 111 \\
\hline November & 92.2 & 125 & 105 & 95.41 & 90.7 & 123.2 & 101.62 & 96.8 & 102 \\
\hline December & 82.2 & 125 & 98 & 91.71 & 52.0 & 76.4 & 87.02 & 999.0 & 93 \\
\hline
\end{tabular}

Source: Calculated from table 3.

\subsection{Seasonal index of fish catch in marine fisheries.}

Egyptian marine fisheries consist of two seas are Mediterranean Sea and Red sea Fisheries, the seasonal index of fish catch in marine fisheries is decreased in May, June, July and August. (Table. 4), because these months are stop fishing period for some fishing crafts in these fisheries, (1/5: 15/6) for the Mediterranean Sea and (1/5:30/8) for Red sea, (GAFRD,2014). Also decreases in December due especially to unsuitable weathering condition at this time in the Mediterranean Sea.

Mediterranean Sea has an especial seasonal index of fish production, which decreases in winter months (November, December, January, and February) when decrease fishing trips, also in the months of stop fishing period, but the seasonality of Red Sea decrease only in the months of stop fishing period (May :June) (GAFRD,2014).

\subsection{Seasonal index of fish catch in lakes fisheries}

Seasonal index of fish catch in lakes fisheries decreases in winter months (December, January, and February) also in the months April and May. So we have to study in details seasonal index of fish catch in the Northern delta lakes, Coastal lagoons, and Inland lakes to find out who is the most influence on Lakes Fisheries Seasonal Index (Table. 4).

Seasonal index of fish catch in Northern delta lakes (Manzala, Burullus, Edku and Mariut) decrease in its value in five months from November to March. Fish catch seasonal index in Coastal lagoons (Barduwil and Port Fouad Saltern) has special nature, because it increases in months from April to July and October. Whereas in Inland lakes (Timsah \& 
Bitter lakes and Suez Canal, Qarun, El Ruyain, New valley fishery, Nasser and Toshka spillway), Its seasonal index of fish catch decrease in the months February, April, May and December (Table 4).

So, seasonal index of fish catch in lakes fisheries decreases because of two reasons:(1) decreasing the temperature in winter months which is unsuitable circumstances for fishing trips, (2) application of stop fishing laws in inland lakes and coastal lagoons (GAFRD, 2014). Hence, climate and fisheries management are the most influential factors in seasonal catch variation in marine and lake natural Egyptian fisheries.

\subsection{Seasonal index of fish catch in fresh water fisheries.}

Fresh water fisheries are the Nile River and its branches, the seasonal index of fish catch in these fisheries decrease in months February, March and from October to December, which are autumn and winter months where they are unsuitable circumstances for fishing trips (Table 4).

It is clear from studying the Seasonal Index of fish catch in natural Egyptian fisheries during the period (2009-2014) that, It outcomes of the seasonality effect of their sources (Table 5), for instance:

(1) In September and December the effect of Seasonal index of fish catch in natural Egyptian fisheries comes from the Seasonality of fish catch in marine, lakes, and freshwater fisheries.

(2) In March, May, October, and November the seasonality of fish catch in marine and lakes fisheries are the responsible of the seasonal index of fish catch in natural Egyptian fisheries.

Table.5. The effect of seasonal index of fish catch in natural Egyptian fisheries during the period (2009-2014)

\begin{tabular}{|c|c|c|c|}
\hline \multirow[b]{2}{*}{ Months } & \multicolumn{3}{|c|}{ Seasonal index of fish catch $(\%)$} \\
\hline & $\begin{array}{l}\text { Bigger value in } \\
(>100)\end{array}$ & $\begin{array}{l}\text { Smaller value in } \\
\qquad(<100)\end{array}$ & $\begin{array}{c}\text { Natural Egyptian } \\
\text { fisheries }\end{array}$ \\
\hline January & M (118), F (101.4) & $\mathrm{L}(94.32)$ & 103 \\
\hline February & $\mathrm{M}(105)$ & L(94.22), F (96.1) & 98 \\
\hline March & M (112) , L (101.73) & $\mathrm{F}(97.2)$ & 104 \\
\hline April & M (106), F (101.0) & $\mathrm{L}(99.42)$ & 102 \\
\hline May & $\mathrm{F}(101.5)$ & M (82), L (94.82) & 92 \\
\hline June & $\mathrm{L}(107.43), \mathrm{F}(101.0)$ & M (76) & 96 \\
\hline July & L (113.33), F (102.6) & $\mathrm{M}(80)$ & 101 \\
\hline August & L(103.83), F (102.3) & M (76) & 94 \\
\hline September & M (110), L (100.73),F (102.8) & - & 104 \\
\hline October & M (132) , L (101.53) & $\mathrm{F}(98.3)$ & 111 \\
\hline November & M (105) , L (101.62) & $\mathrm{F}(96.8)$ & 102 \\
\hline December & - & M (98), L (87.02),F (99.0) & 93 \\
\hline
\end{tabular}

M: Marine Fisheries.

L: Lakes Fisheries. $\quad$ F: Freshwater Fisheries.

Source: Collected from Table 4. 
(3) Seasonal index of fish catch in lakes and freshwater fisheries is the effective resources on seasonal index of fish catch in natural Egyptian fisheries in February and July.

(4) In January and April the seasonal index of fish catch in marine and fresh water fisheries affected on Seasonal index of fish catch in natural Egyptian fisheries.

(5) Finally seasonal index of fish catch in marine fisheries in June and August is the only resources affected on Egyptian natural fisheries Fish catch seasonality.

\section{Seasonal Index of fish prices in natural Egyptian fisheries.}

The study of seasonal index of fish prices, it depends on the data from table 6 . Seasonal index of fish prices in natural Egyptian Fisheries come from variability of seasonality of marine, lakes and freshwater fisheries, which decrease in 4 months (June to September) during the period (2009-2014) - (Table. 7).

Table.6.Monthly average of fish prices in natural Egyptian fisheries during the period (2009-2014)

\begin{tabular}{|c|c|c|c|c|c|c|c|c|c|}
\hline \multirow{2}{*}{ Statement } & \multicolumn{2}{|c|}{ Marine fisheries } & \multirow{2}{*}{$\begin{array}{c}\text { Total } \\
\text { Marine } \\
\text { fisheries }\end{array}$} & \multicolumn{3}{|c|}{ Lakes fisheries } & \multirow{2}{*}{$\begin{array}{c}\text { Total } \\
\text { Lakes } \\
\text { fisheries }\end{array}$} & \multirow{2}{*}{$\begin{array}{c}\text { Fresh } \\
\text { water } \\
\text { fisheries }\end{array}$} & \multirow{2}{*}{$\begin{array}{l}\text { Natural } \\
\text { Egyptian } \\
\text { fisheries }\end{array}$} \\
\hline & $\begin{array}{c}\text { Mediterranean } \\
\text { Sea }\end{array}$ & $\begin{array}{l}\text { Red } \\
\text { Sea }\end{array}$ & & $\begin{array}{c}\text { Northern } \\
\text { delta } \\
\text { lakes }\end{array}$ & $\begin{array}{l}\text { Coastal } \\
\text { lagoons }\end{array}$ & $\begin{array}{c}\text { Inland } \\
\text { lakes }\end{array}$ & & & \\
\hline January & 19.31 & 14.69 & 16.07 & 25.44 & 29.12 & 22.59 & 22.59 & 19.15 & 16.93 \\
\hline February & 19.16 & 14.87 & 16.06 & 25.11 & 28.25 & 22.42 & 22.42 & 19.42 & 16.99 \\
\hline$\overline{\text { March }}$ & 19.56 & 14.95 & 16.31 & 26.16 & 29.23 & 23.23 & 23.23 & 20.37 & 17.39 \\
\hline April & 19.65 & 15.15 & 16.47 & 26.45 & 29.26 & 23.51 & 23.51 & 20.90 & 17.63 \\
\hline$\overline{\text { May }}$ & 18.72 & 14.23 & 15.56 & 25.30 & 28.32 & 22.50 & 22.50 & 19.81 & 16.63 \\
\hline June & 15.43 & 12.09 & 12.73 & 21.37 & 21.94 & 19.32 & 19.32 & 19.68 & 14.25 \\
\hline$\overline{\text { July }}$ & 13.04 & 11.15 & 11.02 & 19.65 & 18.00 & 18.03 & 18.03 & 20.41 & 13.06 \\
\hline August & 12.85 & 10.87 & 10.78 & 20.05 & 18.26 & 18.28 & 18.28 & 21.21 & 12.94 \\
\hline September & 17.66 & 14.54 & 14.65 & 23.87 & 24.79 & 21.66 & 21.66 & 21.31 & 16.18 \\
\hline October & 19.20 & 14.92 & 16.03 & 25.34 & 28.07 & 22.55 & 22.55 & 20.07 & 17.10 \\
\hline November & 20.70 & 15.62 & 17.17 & 27.19 & 30.78 & 24.10 & 24.10 & 20.59 & 18.12 \\
\hline December & 20.81 & 15.83 & 17.27 & 27.27 & 30.86 & 24.25 & 24.25 & 20.66 & 18.23 \\
\hline Total & 216.07 & 168.91 & 180.12 & 293.21 & 316.88 & 262.44 & 262.44 & 243.58 & 195.44 \\
\hline Average & 18.01 & 14.07 & 15.01 & 24.43 & 26.41 & 21.87 & 21.87 & 20.30 & 16.29 \\
\hline
\end{tabular}

Source: Collected from: GAFRD, Yearbook of Fishery Statistics, (2009-2014), Cairo, 2016. 
Table.7.Seasonal index offish prices in natural Egyptian fisheries during the period (2009-2014)

(\%)

\begin{tabular}{|c|c|c|c|c|c|c|c|c|c|}
\hline \multirow{2}{*}{ Statement } & \multicolumn{2}{|c|}{ Marine fisheries } & \multirow{2}{*}{$\begin{array}{c}\text { Total } \\
\text { Marine } \\
\text { fisheries } \\
\text { (M) }\end{array}$} & \multicolumn{3}{|c|}{ Lakes fisheries } & \multirow{2}{*}{$\begin{array}{c}\text { Total } \\
\text { Lakes } \\
\text { fisheries } \\
\text { (L) }\end{array}$} & \multirow{2}{*}{$\begin{array}{c}\text { Fresh } \\
\text { water } \\
\text { fisheries } \\
\text { (F) }\end{array}$} & \multirow{2}{*}{$\begin{array}{l}\text { Natural } \\
\text { Egyptian } \\
\text { fisheries }\end{array}$} \\
\hline & $\begin{array}{l}\text { Mediterranean } \\
\text { Sea }\end{array}$ & $\begin{array}{r}\text { Red } \\
\text { Sea }\end{array}$ & & $\begin{array}{l}\text { Northern } \\
\text { delta } \\
\text { lakes }\end{array}$ & $\begin{array}{l}\text { Coastal } \\
\text { lagoons }\end{array}$ & $\begin{array}{c}\text { Inland } \\
\text { lakes }\end{array}$ & & & \\
\hline January & 107.00 & 105.09 & 106 & 104.34 & 108 & 104 & 104 & 97 & 104 \\
\hline February & 106.21 & 106.24 & 107 & 102.96 & 106 & 103 & 103 & 98 & 105 \\
\hline March & 108.46 & 106.65 & 108 & 107.22 & 110 & 107 & 107 & 102 & 107 \\
\hline April & $\overline{109.04}$ & 107.98 & 109 & 108.36 & 110 & 108 & 108 & 104 & 108 \\
\hline May & 103.89 & 101.26 & 104 & 103.59 & 107 & 103 & 103 & 98 & 102 \\
\hline June & 85.65 & 85.96 & 85 & 87.48 & 83 & 88 & 88 & 97 & 88 \\
\hline$\overline{\text { July }}$ & 72.41 & 79.16 & 73 & 80.42 & 68 & 82 & 82 & 100 & 80 \\
\hline August & 71.40 & 77.05 & 72 & 82.01 & 69 & 83 & 83 & 104 & 79 \\
\hline September & 98.19 & 103.01 & 98 & 97.58 & 95 & 99 & 99 & 103 & 99 \\
\hline October & 106.77 & 105.56 & 107 & 103.58 & 107 & 103 & 103 & 97 & 105 \\
\hline November & 115.16 & 110.34 & 115 & 111.10 & 118 & 110 & 110 & 99 & 111 \\
\hline$\overline{\text { December }}$ & 115.82 & 111.69 & 116 & 111.36 & 119 & 110 & 110 & 99 & 112 \\
\hline
\end{tabular}

Source: Calculated from table 6.

\subsection{Seasonal index of fish prices in marine fisheries.}

The seasonal Index of fish prices in Marine fisheries during the period (2009-2014) is similar to its counterpart in Egyptian national fisheries, where it decreases in June to September (Table 7).

In Mediterranean Sea, Seasonal Index of fish prices is also decreases in June to September. Whereas, seasonal Index of fish prices in Red Sea decreases only in months from June to August.

Hence the seasonal Index of fish prices in Mediterranean Sea fisheries is similar to seasonal Index of fish prices in marine fisheries.

\subsection{Seasonal index of fish prices in lakes fisheries.}

Seasonal Index of fish prices in lakes fisheries - like the seasonal Index of fish prices in Marine and Mediterranean Sea fisheries- also decrease in June to September (Table 7).

Moreover, in studying of seasonal Index of fish prices in lakes fisheries resources, it found that the seasonal Index of fish prices in Northern delta lakes, Coastal lagoons and Inland lakes decrease in months from June to September too.

\subsection{Seasonal index of fish prices in fresh water fisheries.}

The Nile River and its branches has especial seasonal Index of fish prices, which increase only in March, April, July, August and September (Table 7).

Then, the effect of seasonal index of the fish prices in natural Egyptian fisheries during the period (2009-2014) is the outcome of the seasonal effect of their resources (Table 8). 
(1) In March, April and June the effect of seasonal index of fish prices in natural Egyptian comes from seasonal index of the fish prices in marine, lake, and fresh water fisheries.

(2) In other months Marine and Lake seasonal index are the responsible of the seasonal index of the fish prices in natural Egyptian fisheries.

Table.8.The effect of seasonal index of the fish prices in natural Egyptian fisheries of during the period (2009-2014)

\begin{tabular}{|c|c|c|c|}
\hline \multirow[b]{2}{*}{ Months } & \multicolumn{3}{|c|}{ Seasonal index of fish prices $(\%)$} \\
\hline & $\begin{array}{l}\text { Bigger value in } \\
\quad(>100)\end{array}$ & $\begin{array}{l}\text { Smaller value in } \\
\qquad(<100)\end{array}$ & $\begin{array}{c}\text { Natural Egyptian } \\
\text { fisheries }\end{array}$ \\
\hline January & M (106) , L (104) & $\mathrm{F}(97)$ & 104 \\
\hline February & M (107), L (103) & $\mathrm{F}(98)$ & 105 \\
\hline March & M (108), L (107),F (102) & - & 107 \\
\hline April & M (109), L (108),F (104) & - & 108 \\
\hline May & M (104), L (103) & $\mathrm{F}(98)$ & 102 \\
\hline June & - & M (85), L (88), F (97) & 88 \\
\hline July & $\mathrm{F}(100)$ & M(73), L (82) & 80 \\
\hline August & $\mathrm{F}(104)$ & M(72), L (83) & 79 \\
\hline September & $\mathrm{F}(103)$ & M(98), L (99) & 99 \\
\hline October & M (107) , L (103) & $\mathrm{F}(97)$ & 105 \\
\hline November & M (115) , L (110) & $\mathrm{F}(99)$ & 111 \\
\hline December & M (116), L (110) & $\mathrm{F}(99)$ & 112 \\
\hline
\end{tabular}

M: Marine Fisheries.

L: Lakes Fisheries.

F: Freshwater Fisheries.

Source: collected from table 7.

\section{Relationship between seasonal index of fish catch and fish prices in natural Egyptian fisheries.}

By the estimation of correlation coefficient (r) between seasonal index of fish catch $(\%)$ and seasonal index of fish prices (\%) in natural Egyptian fisheries and its resources, it found positive relationship in Egyptian natural fisheries (+0.25), Marine fisheries $(+0.68)$, and Fresh water fisheries $(+0.32)$. but find negative relationship in Lake fisheries (-0.73) (Table 9).

In Egyptian marine fisheries, it was negative relationship in Mediterranean Sea (0.56), and positive relationship in Red Sea (+0.90). But in Egyptian lakes fisheries, it was negative relationship in Northern delta lakes (-0.87), Coastal lagoons (-0.11), and Inland lakes (-0.18) (Table 10). 
Table 9.Relationship between fish catch and fish prices in Egyptian natural fisheries during the period (2009-2014)

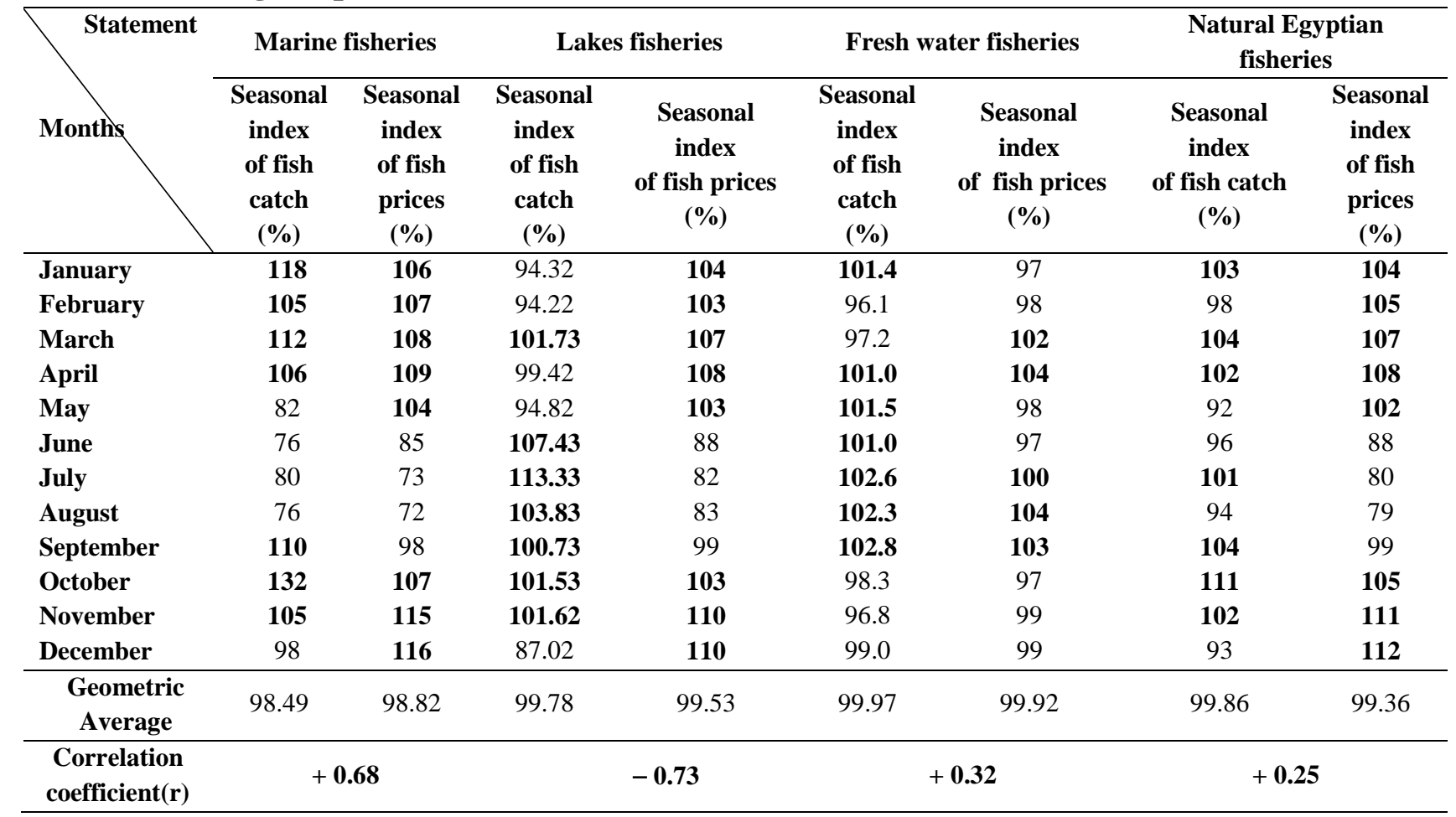

$$
\mathrm{r}=\frac{}{\sqrt{\left[n \Sigma x^{2}-(\Sigma x)^{2}\right]\left[n \Sigma y^{2}-(\Sigma y)^{2}\right]}} \text {. }
$$

Source: Collected from Tables 4 \& 7 .

Hence, it is concluded that: (1) it is important to increase, or at least maintain fish catch in total Egyptian natural fisheries, total fresh water fisheries, total marine fisheries, and individual Red Sea fisheries due to the positive relationship between fish catch seasonal index (\%) and fish prices seasonal index. (2) More and actual effective developing programs must be applied in total lakes fisheries and individual Mediterranean Sea fisheries to overcome the present negative relationship between seasonal index of fish catch and fish prices. 
Table 10. Relationship between fish catch and fish prices in Egyptian marine and lakes fisheries during the period (2009-2014)

\begin{tabular}{|c|c|c|c|c|c|c|c|c|c|c|}
\hline \multirow{3}{*}{$\begin{array}{l}\text { Statement } \\
\text { Months }\end{array}$} & \multicolumn{4}{|c|}{$\begin{array}{c}\text { Seasonality index in Egyptian marine } \\
\text { fisheries }\end{array}$} & \multicolumn{6}{|c|}{ Seasonality index in Egyptian lakes fisheries } \\
\hline & \multicolumn{2}{|c|}{ Mediterranean Sea } & \multicolumn{2}{|c|}{ Red Sea } & \multicolumn{2}{|c|}{ Northern delta lakes } & \multicolumn{2}{|c|}{ Coastal lagoons } & \multicolumn{2}{|c|}{ Inland lakes } \\
\hline & $\begin{array}{c}\text { Seasonal } \\
\text { index } \\
\text { of fish } \\
\text { catch } \\
(\%)\end{array}$ & $\begin{array}{c}\text { Seasonal } \\
\text { index } \\
\text { of fish } \\
\text { prices } \\
(\%)\end{array}$ & $\begin{array}{c}\text { Seasonal } \\
\text { index } \\
\text { of fish } \\
\text { catch } \\
(\%)\end{array}$ & $\begin{array}{c}\text { Seasonal } \\
\text { index } \\
\text { of fish } \\
\text { prices } \\
(\%)\end{array}$ & $\begin{array}{c}\text { Seasonal } \\
\text { index } \\
\text { of fish } \\
\text { catch } \\
(\%)\end{array}$ & $\begin{array}{c}\text { Seasonal } \\
\text { index } \\
\text { of fish } \\
\text { prices } \\
(\%)\end{array}$ & $\begin{array}{c}\text { Seasonal } \\
\text { index } \\
\text { of fish } \\
\text { catch } \\
(\%)\end{array}$ & $\begin{array}{c}\text { Seasonal } \\
\text { index } \\
\text { of fish } \\
\text { prices } \\
(\%)\end{array}$ & $\begin{array}{c}\text { Seasonal } \\
\text { index } \\
\text { of fish } \\
\text { catch } \\
(\%)\end{array}$ & $\begin{array}{c}\text { Seasonal } \\
\text { index } \\
\text { of fish } \\
\text { prices } \\
(\%)\end{array}$ \\
\hline January & 97.2 & 107.00 & 151 & 105.09 & 93.81 & 104.34 & 10.0 & 108 & 101.7 & 104 \\
\hline February & 99.3 & 106.21 & 114 & 106.24 & 95.71 & 102.96 & 0.0 & 106 & 96.5 & 103 \\
\hline March & 101.3 & 108.46 & 128 & 106.65 & 96.52 & 107.22 & 0.0 & 110 & 126.0 & 107 \\
\hline April & 105.3 & 109.04 & 108 & 107.98 & 100.22 & 108.36 & 177.3 & 110 & 90.6 & 108 \\
\hline May & 68.2 & 103.89 & 103 & 101.26 & 100.92 & 103.59 & 309.9 & 107 & 56.7 & 103 \\
\hline June & 97.2 & 85.65 & 42 & 85.96 & 104.82 & 87.48 & 157.0 & 83 & 111.0 & 88 \\
\hline July & 114.2 & 72.41 & 27 & 79.16 & 114.82 & 80.42 & 108.9 & 68 & 109.6 & 82 \\
\hline August & 119.3 & 71.40 & 8 & 77.05 & 104.82 & 82.01 & 84.7 & 69 & 103.3 & 83 \\
\hline September & 118.3 & 98.19 & 96 & 103.01 & 101.22 & 97.58 & 94.8 & 95 & 100.0 & 99 \\
\hline October & 105.3 & 106.77 & 173 & 105.56 & 100.02 & 103.58 & 114.7 & 107 & 105.0 & 103 \\
\hline November & 92.2 & 115.16 & 125 & 110.34 & 95.41 & 111.10 & 90.7 & 118 & 123.2 & 110 \\
\hline December & 82.2 & 115.82 & 125 & 111.69 & 91.71 & 111.36 & 52.0 & 119 & 76.4 & 110 \\
\hline $\begin{array}{l}\text { Geometric } \\
\text { Average }\end{array}$ & 98.92 & 98.79 & 78.84 & 99.26 & 99.83 & 99.42 & - & 98.42 & 98.04 & 99.53 \\
\hline $\begin{array}{c}\text { Correlation } \\
\text { coefficient } \\
\text { (r) }\end{array}$ & \multicolumn{2}{|c|}{-0.56} & \multicolumn{2}{|c|}{+0.90} & \multicolumn{2}{|c|}{-0.87} & \multicolumn{2}{|c|}{-0.11} & \multicolumn{2}{|c|}{-0.18} \\
\hline \multicolumn{3}{|c|}{$\mathrm{n}\left(\sum \mathrm{xy}\right)-\left(\sum \mathrm{x}\right)\left(\sum \mathrm{y}\right)$} & \multicolumn{8}{|c|}{ Source: Collected from Tables 4 \& 7.} \\
\hline
\end{tabular}

\section{REFERENCES}

AgriLIFE EXTENSION. Howto Constract aSeasonal Index (Lecture on line), Texas A\&N System.

Carbunaru, B.A., and Bacescu, C.M. (2013), Methods Used in the Seasonal Variation Analysis of Time Series. Romanian Statistical Review (RSR), (3): 13pp.

Genreal Authority for Fish Resources Development (GAFRD). Year-book of fishery statistics (2009-2014), Cairo, Egypt,2016.

Maiyza, SH. I. (2015), An Economic study of Fish Production In Alexandria Mediterranean Sea Fisheries, Ph.D., Faculty of Agriculture, Alexandria University :pp.156-158.

Water Quality Assessment, (1996), A Guide to Use of Biota, Sediment and Water in Environmental Monitoring- Second Edition,Chapter 7, UnitedNations, Eductional, Scientificand Culture Organization(UNESCO), World Health Organization (WHO), United Nations Environment Programme (UNEP). 